\title{
Happy PK Competition in Class
}

\author{
Xuejing SONG* \& Shixiao YANG \\ City College of Dongguan University of Technology, Dongguan, 523419, China \\ *Corresponding Author
}

\begin{abstract}
In recent years, PK competition has become very popular with TV entertainment shows. On such basis, this work introduced PK competition into classroom teaching in colleges and universities to improve the entertaining function of the class and students' participation in classroom teaching. In order to carry out happy PK competition in class smoothly, teachers should make some changes in their teaching attitude and method. PK competition in classroom teaching focuses on the participation, competition of students, and the entertaining function of the class. Besides, this new teaching mode strives to achieve maximum teaching effects and create the atmosphere where students can compete and study happily.
\end{abstract}

KEYWORD: Competition in Class; PK in Class; Teaching Methods; Teaching Experience

\section{INTRODUCTION}

PK competition on TV shows has attracted a large number of young people. Besides, those entertainment shows have won millions of audiences including the old and the young due to their colorful, entertaining and competitive content. Traditional shows were dull, boring, outdated and unwatchable, failing to attract the majority of audiences. PK competition changed such situation. Such innovation leads the thought of introducing PK competition into traditional classroom teaching in order to cater to students' interests. Thus, students in classroom can positively participate in class rather than negatively listen to teachers. Besides, it helps to stimulate students' competitive awareness, so they can actively cooperate with teachers and participate in class.

\section{NECESSITY TO CHANGE THE TEACHING ATTITUDE AND METHOD}

Teachers should change their teaching attitude in order to enable students to study happily in class. Firstly, "teacher-oriented" attitude should be changed into "student-oriented attitude", constructing the atmosphere of "cooperation of teachers and students". Secondly, they should change the idea of "distinguishing students educable or uneducable" into "all people the same and no distinction of education". Thirdly, "the noble position of teachers" should be forgotten. In stead, they should learn from the proverb - "low water forms a sea, low profile makes a king". In addition to change the teaching attitude, teachers need to change their teaching method. In modern education interactive teaching should be used instead of spoonfeeding teaching in class. The exact changes of teaching method are as tab 1 :

Table 1. Different teaching methods

\begin{tabular}{|l|l|}
\hline Traditional Teaching Method & Interactive Teaching Method \\
\hline Telling & Questioning \\
\hline Lecturing & Supporting and Facilitating \\
\hline $\begin{array}{l}\text { Teaching according to } \\
\text { textbook teaching outline }\end{array}$ & $\begin{array}{l}\text { Designing activities to } \\
\text { prompt self-study }\end{array}$ \\
\hline Unilateral Communication & Bilateral Interaction \\
\hline
\end{tabular}

The changes of teachers' teaching method are mainly reflected in the teaching activities. PK competition on TV shows always attracts a lot of young people. Therefore, if PK competition is introduced into classroom teaching to help students study happily, the traditional teaching method will experience huge changes. Generally, teaching activities are designed for groups. Especially in some independent colleges, one class contains many students. It will take much time for teachers to apply single PK competition in one class. Thus, as for classes with many students, teachers need to divide the class into several groups with 6-10 students in one group. So, group members can share their knowledge and experiences within the group, and 
then each group can choose one representative to compete with other groups. In order to stimulate students' participation enthusiasm, teachers can give each group the authority to select their own "leaders" and grant them certain responsibilities and honors, thus stimulating their enthusiasm. Besides, "assistant" system can be set up, which means teacher can assign one assistant for each "group leader". As a result, every group member in fact has a title, thus inspiring their sense of responsibility and their psychology of winning.

\section{EMPHASIS OF PK COMPETITION IN CLASSROOM TEACHING}

PK competition should be entertaining, competitive and participatory in classroom teaching. Besides, teachers should take some measures to help students strengthen the knowledge they learn in class.

\subsection{Entertainment}

As for the entertainment of PK competition, 4 aspects should be considered in the teaching process. The first is the encouraging slogan in class. In entertainment shows, each participant will shout their slogan out loudly, which helps to boost their moral and also increase the entertaining effect. While in class, most students feel unconfident when they are asked some questions. They may doubt their answers or worry that other students may laugh at them. Therefore, teachers should use some slogans to encourage them to answer the question, or they can make some encouraging gestures such as a thumb-up when someone answers the question correctly. The second is the reward and punishment system in class. In fact, students' positive behaviors need actively encouragement. On contrary, the negative behaviors should be punished. Students feel happy when they get rewards. But when it comes to punishment for students, teachers should carefully consider the punitive measures. Generally, there are two ways to make the punishment easier accepted by students. One is in physical way, and the other in entertainment way. The physical way requires students do some physical activities such as pushups or running as a punishment. The entertainment way needs students to give an entertaining performance as the punishment. The third is the break-time entertainment. Teachers should pay more attention to the 10-minute break. Many students try to get some sleep during the 10 minutes. But once falling asleep, they may feel sleepy in the next class. So teachers can play some significant videos during the break time in order to attract students' attention. Thus, students will not fall asleep, ensuring enough energy for the next class. The fourth is various ways of raising questions. Teachers can imitate the quiz show on TV shows, using various ways to raise questions, such as drawing lots, strike questioning, raising plate, and quickly-responding questions.

\subsection{Participation}

Some teaching sections need the participation of students. In fact, teachers just play the role as guides in classes, and students are the dominance in classes. In practical teaching, teachers can treat themselves as a host, guiding the class to make more students involved in. With the guidance of teachers, students can share their knowledge within the group, and then each group selects one representative to share the knowledge with the whole class. Students are equal and emotional. They focus more on what their companions say, easy to accept the opinions of their companions. Therefore, it is very important for students to share their knowledge. In addition, roleplay is another way to involve students in class. This teaching method has been applied in many aspects. Here the work did not describe more about it.

\subsection{Competition}

The full name of PK is Player Killer, originated from a MUD game. It refers to killing other players rather than cooperating with other players in the game. Later, PK was extended to the meaning of "fight". "Fight" cannot lack competitiveness. In order to make students understand the spirit of competition and the significance of cooperation, it is necessary to establish a competition relationship among groups and a cooperation relationship within groups. The referee of $\mathrm{PK}$ competition is one member from a group each time. The score and ranking will be published after the PK competition. Besides, the collective score and ranking of each group will be published regularly, thus making use of students' sense of group honor to inspire their participation and competitive awareness.

\subsection{Measures to help students strengthen the knowledge}

All learning activities should be results-oriented, so students do not only pay attention to the entertainment of the class. In stead, they should pay more attention to what they can gain from the class. Meanwhile, it is necessary for students to strengthen their knowledge. In another words, it is very important to summarize the knowledge they have learned. The summarizing of knowledge after class is called "tightening the bag". Each study group should share what they have learned with other groups, and then teachers summarize the knowledge. Besides, when the curriculum gets to a certain stage, teachers should apply in-class quizzes. The score of each group member should be converted and added 
to the total PK competition score of each group. Teachers cannot inform students about the in-class quiz in advance. In stead, teachers should arrange sudden quiz so as to achieve maximum learning outcomes. Thus, students will not just study for quizzes. Besides, in order to establish good affection among group members, teachers can design some small activities about the teaching content, and require all group members to participate in. Thus, the content of the class can be further strengthened through these small activities.

\subsection{Comparison of the results}

Teaching evaluation index before and after using the PK teaching method shown in table 2:

Table 2. Comparison of teaching evaluation index

\begin{tabular}{|l|c|c|}
\hline Evaluation index of teaching & before & now \\
\hline Rate of attendance & $82 \%$ & $96 \%$ \\
\hline Student evaluation of teaching & 88.32 & 95.8 \\
\hline Average Score & 73.6 & 86.5 \\
\hline students' participation & $30 \%$ & $90 \%$ \\
\hline
\end{tabular}

From tab2, we can find that by using PK teaching method, the teaching evaluation indexes are all improved. Especially the participation of students and student evaluation of teaching, these are we all want to see.

\section{CONCLUSIONS}

In conclusion, in order to improve the quality of teaching, teachers should firstly change their teaching attitude and method. PK competition in classroom teaching emphasizes more on the participation and competition of students as well as the entertaining function of the class. Besides, this new teaching mode strives to achieve maximum teaching effects. Therefore, students can carry out PK competition happily in class and study happily at the same time.

\section{ACKNOWLEDGEMENT}

This project was supported and funded by Foundation for Young Teachers, Teaching Quality and Teaching Reform Project of Institutions of Higher Education in Guangdong Education Department (Quality Engineering), Special funds for Discipline and Specialty Construction of Institutions of Higher Education in Guangdong Education Department (Seedling Project), Training plan of Guangdong Province outstanding young teachers in Higher Education Institutions.

\section{REFERENCES}

[1] Lu Guizhen. On shills Applied in Experiential Teaching Sharing Session. Journal of Qiongzhou University, 2012(12), 19:61-63

[2] Guan Lijing, Yang Xiaoming. Experimental Study on "PK" Tesching Mode in Class Teaching of Professional Sports Aerobics. Journal of Southwest China Normal University, 2012(12), 37:165-169

[3] YAO Li-qin. Analysis on Reaction of Lost about University Fair Sex of Differ Attribution-Set the demonstration research on aerobics of player kill as an example. 2009(6), 31: 127-129 